\title{
Bacteriology of wild grey mullets, Mugil platanus Günther, from Cananéia, São Paulo State, Brazil
}

\author{
José Américo de Sousa ${ }^{1}$ \\ Jorge da Costa Eiras ${ }^{1}$ \\ Maria José T. Ranzani-Paiva ${ }^{2}$ \\ Agar Costa Alexandrino ${ }^{2}$
}

\begin{abstract}
Bacterial strains isolated from the kidney and liver of grey mullets, Mugil platanus Günther, 1880, captured in Cananéia, São Paulo State, Brazil, in October 1996, belong to the genera Micrococcus, Pseudomonas, Flavobacterium, Aeromonas and Vibrio. The resistance/susceptibility patterns of the isolated micro-organisms to nine antimicrobial substances were determined, the more resistant bacteria had been Pseudomonas, Flavobacterium and Micrococcus. To the best of the authors knowledge this is the first bacteriological study done on Mugil platanus in Brazil.

KEY WORDS. Mugil platanus, grey mullets, fish, bacteriology, Brazil
\end{abstract}

Most of the bacteriological studies that have been done on fish concern their external surfaces (skin and gills) or their digestive tracts (HORSLEY 1973; SUGITA et al. 1985; SAKATA 1989). In general, these studies indicate that the bacterial communities present on the external surfaces of fishes reflect the bacterial load of the water in which these aquatic vertebrates are living, while the microbial diversity present in the digestive tracts is almost always much lower than in the water.

Nevertheless, some research has been made on the bacteria present in fishes' internal organs, and some epizootics in wild fish populations have been reported (TorANZO et al. 1989, 1993; CAHILL 1990). As the spleen, the liver and the kidneys should be sterile in healthy fishes, the presence of bacteria in these organs could indicate breakdown of immunological defence mechanisms as the result of stress caused by factors such as poor water quality, temperature changes, nutritional deficiencies, overcrowding, trauma, parasitism or primary viral infections. Once in the internal organs, these micro-organisms would eventually either be destroyed or survive to initiate an infection (CAHILL 1990).

Various groups of bacteria were reported as occurring in association with the external surfaces, alimentary tract and internal organs of fishes belonging to different species and living in marine environments, including Pseudomonas, Vibrio, Flavobacterium, Cytophaga, Aeromonas, Micrococcus, Staphylococcus, Coryneforms, Acinetobacter, Moraxella, Bacillus and, to a much lesser extent, Enterobacteriaceae (SAKATA 1989; CAHILL 1990).

1) Departamento de Zoologia e Antropologia, Faculdade de Ciências, Universidade do Porto. 4050 Porto, Portugal.

2) Instituto de Pesca. Avenida Francisco Matarazzo 455, 05031-900 São Paulo, São Paulo, Brasil.

E-mail: mranzanipaiva@uol.com.br 
A number of studies have been done on the parasitology (CONROY \& CONROY 1984; CONROY et al. 1985; EIRAS et al. 1995; LIMA 1976; RANZANI-PAIVA et al. 1997), haematology (RANZANI-PAIVA 1995a,b) and histopathology (PÉREZ et al. 1996) was done concerning the grey mullet, Mugil platanus Günther, 1880, caught from Brazilian waters. The information gathered by those studies, as well as the data on the biology of the species, are important once they can contribute to the adoption and implementation of prophylactic measures prior to the use of mullet for farming.

In this paper some data on the first bacteriological examination of Mugil platanus from Cananéia are presented.

\section{MATERIALS AND METHODS}

Sampling of the twenty two grey mullets (total length: $33.0-68.5 \mathrm{~cm}$; total weight: $390-2,380$ g) used in this study took place in Cananeia, São Paulo, in October 1996. The fishes were caught by gill nets and immediately transported to the laboratory and sacrificed.

For bacteriological examination, samples of kidney and liver of every fish were aseptically taken and streaked directly onto Tryptic Soy Agar (TSA; Difco). Plates were incubated at $22^{\circ} \mathrm{C}$ for $48-72$ hours. Representative colonies of the different morphological types were isolated and restreaked in fresh medium, until pure cultures were obtained (THOESEN 1994).

Pure cultures of the isolated bacteria were subjected to standard morphological, physiological and biochemical tests, and their taxonomic position was determined following the schemes of AUSTIN \& ALLEN-AUSTIN (1993), HOLT et al. (1994), SMIBERT \& KRIEG (1994) and THOESEN (1994).

The disc diffusion method on Mueller-Hinton agar (MHA; Difco) was used to determine the susceptibility/resistance of all the isolates to the following antimicrobial substances: vibriostatic agent $\mathrm{O} / 129(150 \mu \mathrm{g})$ (used only for identification purposes), furazolidone $(50 \mu \mathrm{g})$, oxolinic acid $(2 \mu \mathrm{g})$, norfloxacin $(10 \mu \mathrm{g})$, oxytetracycline $(30 \mu \mathrm{g})$, tetracycline $(30 \mu \mathrm{g})$, chloramphenicol $(30 \mu \mathrm{g})$, ampicillin $(10 \mu \mathrm{g})$, streptomycin $(10 \mu \mathrm{g})$ and trimethoprim-sulphamethoxazole $(23.75-1.25 \mu \mathrm{g})$.

\section{RESULTS AND DISCUSSION}

Nine out of the twenty two (41\%) fishes analysed harboured at least one bacterial strain in their internal organs. Table I shows the bacterial groups detected, as well as the number of strains isolated in pure or mixed cultures. The isolation of strains belonging to Micrococcus, Pseudomonas, Flavobacterium, Aeromonas and Vibrio is not surprising, because these groups are commonly represented in the bacterial communities detected in association with marine fish species, whether they are wild or cultured (SAKATA 1989; CAHILL 1990).

The resistance/susceptibility patterns of the studied bacteria to the antibacterial substances used (besides vibriostatic agent $\mathrm{O} / 129$, used only for identification purposes) are shown in table II. The higher percentage (62\% of the strains) of resistance was found against furazolidone, followed by oxolinic acid (38\%), norfloxacin and streptomycin (31\%). Only one strain ( $8 \%$ ) was resistant to oxytetra- 
cycline and to trimethoprim-sulphamethoxazole, while, among the three strains resistant to ampicillin, two are motile Aeromonas, which are known for showing no susceptibility to this antimicrobial compound (TORANZO et al. 1989). Finally, all the strains were susceptible to tetracycline and chloramphenicol. Strains susceptible to all the drugs used were found in Pseudomonas, Flavobacterium and Vibrio. Also both strains of Aeromonas showed no resistance to any of the antibacterial substances used except to ampicillin. Resistance only against furazolidone was found in one strain belonging to Pseudomonas and another belonging to Vibrio.

Table I. Number of strains isolated from grey mullets internal organs, in pure or mixed cultures.

\begin{tabular}{lccl}
\hline \multicolumn{1}{c}{ Strains } & Pure cultures & Mixed cultures & \multicolumn{1}{c}{ With } \\
\hline Micrococcus & 1 & 0 & - \\
Pseudomonas & 2 & 3 & $\begin{array}{l}\text { Flavobacterium } \\
\text { Aeromonas } \\
\text { Vibrio }\end{array}$ \\
Flavobacterium & 2 & & $\begin{array}{l}\text { Pseudomonas } \\
\text { Pseudomonas } \\
\text { Aeromonas }\end{array}$ \\
Vibrio & 0 & 1 & $\begin{array}{l}\text { Aeromonas } \\
\text { Pseudomonas }\end{array}$ \\
\hline
\end{tabular}

Table II. Resistance/Susceptibility profiles exhibited by the different bacterial strains isolated. (FUR) Furazolidone, (OA) oxolinic acid, (NOR) norfloxacin, (OT) oxytetracycline, (T) tetracycline, (C) chloramphenicol, (AMP) ampicillin, (S) streptomycin, (SXT) trimethoprim-sulphamethoxazole, (R) resistant, (S) susceptible.

\begin{tabular}{|c|c|c|c|c|c|c|c|c|c|c|}
\hline Strains & $\begin{array}{c}\text { Number os strains } \\
\text { with profile }\end{array}$ & $\begin{array}{l}\text { FUR } \\
50 \mu \mathrm{g}\end{array}$ & $\begin{array}{l}\mathrm{OA} \\
2 \mu \mathrm{g}\end{array}$ & $\begin{array}{l}\text { NOR } \\
10 \mu \mathrm{g}\end{array}$ & $\begin{array}{l}\text { OT } \\
30 \mu \mathrm{g}\end{array}$ & $\begin{array}{c}\mathrm{T} \\
30 \mu \mathrm{g}\end{array}$ & $\begin{array}{c}\mathrm{C} \\
30 \mu \mathrm{g}\end{array}$ & $\begin{array}{l}\text { AMP } \\
10 \mu \mathrm{g}\end{array}$ & $\stackrel{S}{S}$ & $\begin{array}{l}\mathrm{SXT} \\
25 \mu \mathrm{g}\end{array}$ \\
\hline Micrococcus & 1 & $\mathrm{R}$ & $\mathrm{R}$ & R & S & S & S & S & S & S \\
\hline \multirow[t]{3}{*}{ Pseudomonas } & 1 & S & $\mathrm{S}$ & $\mathrm{S}$ & $\mathrm{S}$ & $\mathrm{S}$ & S & $\mathrm{S}$ & $\mathrm{S}$ & $\mathrm{S}$ \\
\hline & 1 & $\mathrm{R}$ & $S$ & $\mathrm{~S}$ & $\mathrm{~S}$ & $\mathrm{~S}$ & $\mathrm{~S}$ & $\mathrm{~S}$ & $S$ & $S$ \\
\hline & 3 & $\mathrm{R}$ & $\mathrm{R}$ & $\mathrm{R}$ & $\mathrm{S}$ & $\mathrm{S}$ & $S$ & S & $\mathrm{R}$ & S \\
\hline \multirow[t]{3}{*}{ Flavobacterium } & 1 & $\mathrm{~S}$ & S & $\mathrm{S}$ & $\mathrm{S}$ & $\mathrm{S}$ & $\mathrm{S}$ & $\mathrm{S}$ & $\mathrm{S}$ & $\mathrm{S}$ \\
\hline & 1 & $\mathrm{R}$ & $\mathrm{R}$ & $\mathrm{S}$ & $\mathrm{S}$ & $\mathrm{S}$ & $\mathrm{S}$ & $\mathrm{S}$ & $\mathrm{S}$ & $\mathrm{R}$ \\
\hline & 1 & $\mathrm{R}$ & $\mathrm{S}$ & S & $\mathrm{R}$ & $\mathrm{S}$ & $\mathrm{S}$ & $\mathrm{R}$ & $\mathrm{R}$ & S \\
\hline Aeromonas & 2 & $\mathrm{~S}$ & S & $\mathrm{S}$ & S & $\mathrm{S}$ & $\mathrm{S}$ & $\mathrm{R}$ & S & S \\
\hline \multirow[t]{2}{*}{ Vibrio } & 1 & $\mathrm{~S}$ & $\mathrm{~S}$ & $\mathrm{~S}$ & $\mathrm{~S}$ & $\mathrm{~S}$ & $\mathrm{~S}$ & $\mathrm{~S}$ & $\mathrm{~S}$ & $\mathrm{~S}$ \\
\hline & 1 & $\mathrm{R}$ & $\mathrm{S}$ & $\mathrm{S}$ & $\mathrm{S}$ & $\mathrm{S}$ & $\mathrm{S}$ & S & $\mathrm{S}$ & $\mathrm{S}$ \\
\hline
\end{tabular}

Strains resistant to more than one drug were detected in Flavobacterium (1 strain resistant to furazolidone and oxolinic acid, and one strain resistant to furazolidone, oxytetracycline, ampicillin, streptomycin and trimethoprim-sulphamethoxazole), Micrococcus (resistance to furazolidone, oxolinic acid and norfloxacin) and Pseudomonas (three strains resistant to furazolidone, oxolinic acid, norfloxacin and streptomycin). Curiously the strains resistant to more drugs simultaneously belonged to the groups of aerobic Gram-negative bacteria Pseudomonas and Flavobacterium, as well as to the Gram-positive genus Micrococcus. According to TORANZO et al. (1992), the resistance to these drugs usually employed in aquaculture seems to be a common feature of the strains of these genera isolated from fish culture systems. 
Taking into consideration the present results, as well as the toxicity of chloramphenicol, tetracycline would be the drug of choise to treat any infection caused by one of these bacteria.

In spite of the limitations of this study, it represents the first bacteriological study of M. platanus in Brazil. Further studies are necessary to a better knowledge of the pathology of the wild populations of this species.

\section{REFERENCES}

Austin, B. \& D. Allen-Austin. 1993. Bacterial fish pathogens. Disease in farmed and wild fish. Chichester, Ellis Horwood Ltd., 384p.

CAHILL, M.M. 1990. Bacterial flora of fishes: a review. Microbiol. Ecol. 19: 21-41. CONROY, G. \& D.A. ConRoy. 1984. Diseases and parasites detected in grey mullets (Mugilidae) from coastal waters of São Paulo State, Brazil. I. Adult silver mullet (Mugil curema Val., 1836). R. Ital. Piscicolt. Ittiopat. 19 (1): 14-28.

Conroy, G.; D.A. Conroy \& P.S. CeCCARelli. 1985. Diseases and parasites detected in grey mullets (Mugilidae) from coastal waters of São Paulo State, Brazil. II. Juvenile silver mullet (Mugil curema Val., 1836). R. Ital. Piscicolt. Ittiopat. 20 (2): 74-76.

EIRAS, J.C.; M.J.T. RANZANi-PAIVA \& A.J. DavieS. 1995. Observations on Haemogregarina mugili (Apicomplexa) and Trypanosoma froesi (Sarcomastigophora) from the blood of Mugil platanus Günther, 1880 (Pisces: Mugilidae) in Brazil. Res. Rev. Parasitol. 55 (3): 173-176.

Holt, J.G.; N.R. Krieg; P.H.A. Sneath; J.T. Staley S.T. \& Williams. 1994. Bergey's manual of determinative bacteriology. Baltimore, Williams \& Wilkins, $9^{\text {th }}$ ed., 787p.

Horsley, R.W. 1973. The bacterial flora of the Atlantic salmon (Salmo salar L.) in relation to its environment. Jour. Appl. Bacteriol. 36: 377-386.

LIMA, D.F. 1976. Uma nova espécie de tripanosoma na tainha (Mugil brasiliensis Agassiz, 1929) (Pisces, Mugilidae). Rev. Brasil. Biol. 36: 167-169.

Pérez, A.C.A.; M.J.T. RanZani-Paiva; S. Arana; J. Mandelli JR.; M.H. CARVALHO. 1996. Relato de carcinoma hepatocelular em tainha, Mugil platanus (Osteichthyes, Mugilidae) da região estuarino-lagunar da Cananéia (Lat. $25^{\circ} 00^{\prime}$ S-Long. $47^{\circ} 55^{\prime}$ W) Estado de São Paulo, Brasil. Rev. Bras. Med. Vet. 18 (5): 206-210.

RANZANI-PAIVA, M.J.T. 1995a. Características hematológicas de tainha, Mugil platanus Günther, 1880 (Osteichthyes, Mugilidae) da região estuarino-lagunar

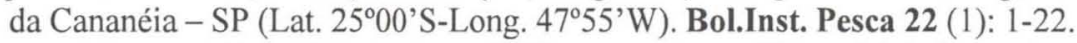

-1995b. Células do sangue periférico e contagem diferencial de leucócitos de tainha, Mugil platanus Günther, 1880 (Osteichthyes, Mugilidae) da região estuarino-lagunar da Cananéia - SP (Lat. $25^{\circ} 00^{\prime}$ S-Long. $47^{\circ} 55^{\prime} \mathrm{W}$ ). Bol. Inst. Pesca 22 (1): 23-40.

RANZANI-PAIVA, M.J.T.; C.M. ISHIKAwa; B.E.S. CAMPos \& A.C. EIRAS. 1997. Haematological characteristics associated with parasitism in mullets, Mugil platanus Günther, from the estuarine region of Cananéia, São Paulo, Brazil. Revta bras. Zool. 14 (2): 329-339.

SAKATA, T. 1989. Microflora of healthy animals, p.141-163. In: AUSTIN B \& D.A. 
AUSTIN (Eds). Methods for the microbiological examination of fish and shellfish. Chichester, Ellis Horwood Ltd., 384p.

SMiBert, R.M. \& N.R. KRIEG. 1994. Phenotypic Characterization, p.607-654. In: P. Gerhardt; R.G.E. Murray; W.A. Wood \& N.R. Krieg (Eds). Methods for general and molecular bacteriology. Washington, D.C., American Society for Microbiology, 791p.

Sugita, H.; S. UshioKA; D. Kinara \& Y. Deguchi. 1985. Changes in the bacterial composition of water in a carp rearing tank. Aquaculture 44: 243-247.

THOESEN, J.C. 1994. Suggested procedures for the detection and identification of certain finfish and shellfish pathogens. Bethesda, Fish Health Section, American Fisheries Society, $4^{\text {th }}$ ed., 322p.

Toranzo, A.E.; A.M. BAyA; J.L. RomaldE \& F.M. HeTriCK. 1989. Association of Aeromonas sobria with mortalities of adult gizzard shad, Dorosoma cepedianum Lesueur. Jour. Fish Dis. 12: 439-448.

Toranzo, A.E.; J.L. Romalde; I. Bandín; Y. SANTOS \& J.L. BARJA. 1992. Evaluation of the sensitivity of bacterial fish pathogens to different antimicrobial compounds, p.315-325. In: C. MiCHEL \& D.J. ALDERMAN (Eds). Chemotherapy in aquaculture: from theory to reality. Paris, Office International des Epizooties (OIE), 567p.

Toranzo, A.E.; B. Novoa; J.L. Romalde; S. NúÑEZ; S. Devesa; E. Mariño; R. Silva; E. MartíneZ; A. Figueras \& J.L. BARJA. 1993. Microflora associated with healthy and diseased turbot (Scophthalmus maximus) from three farms in northwest Spain. Aquaculture 114: 189-202.

Recebido em 25.V.1998; aceito em 29.IX.1999 